\title{
Teacher Optimization in Utilizing Media Literacy for Social Science Learning in Semarang
}

\author{
https://doi.org/10.3991/ijet.v15i07.13227 \\ Khoirul Anwar ${ }^{(凶)}$, Fitri Amalia Shintasiwi, Ferani Mulianingsih \\ Universitas Negeri Semarang, Semarang, Indonesia \\ irulanwar@mail.unnes.ac.id
}

\begin{abstract}
This research aims to know the utilization of media literacy by teachers and the obstacles in social science learning in Semarang city. This research is a field research carried out through an inductive thinking process using qualitative approach. The type of data in this research is distinguished from primary and secondary data. The data sources in this research are human being and non-human being. Human being data source functions as a subject or key informant and the data obtained through the informants are in the form of soft data. Nonhuman being data source is in the form of documents which are relevant to the focus of the research such as events or activities that are related to the focus of the research. The data collection uses three techniques, namely (1) in-depth interview; 2) participant observation; and (3) documentation study. The data obtained were analyzed by stages, namely 1) data reduction 2) data presentation and 3 ) conclusion / verification. The results of the research show that the teachers were trying to adjust to various updates in the media development. This self-adjustment was realized through the integration of both of them in learning regardless of several obstacles that must be faced by the teachers.
\end{abstract}

Keywords - Globalization in Education, Social Science Teacher, Media Literacy.

\section{Introduction}

Today, literacy movement is a necessity. This is not without reason. Based on the results of the observation of Ministry of Education and Culture (Dikdasmen, 2016), the results of the Progress International Reading Literacy Study (PIRLS) test in 2011 which evaluated the reading ability of fourth-grade students placed Indonesia in 45th place out of 48 participating countries with a score of 428 , below the average value of 500 . Meanwhile, the survey evaluating the ability of 15-year-old students was conducted by Programme for International Student Assessment (PISA) which includes reading, mathematics, and science. Indonesian students participated in the PISA 2009 and 2012 which both of them were attended by 65 participating countries. Particularly in reading ability, Indonesia was originally ranked 57th in PISA 2009 with a score of 396 (average score of 439). However, it turned out that in PISA 2012, the ranking decreased to 64th with a score of 396 (average score 496). The data are in line with the findings of UNESCO 
in 2012 concerning the reading habits of the Indonesian people that there is only one of 1,000 Indonesian people who reads. This condition is very alarming because reading ability is the basis for the acquisition of knowledge, skills, and the formation of student attitudes.

Teachers, in the dimension of learning especially in the classroom, are generally known as learning resources for students. One of the teacher's roles is indeed as a source of learning, but this is no longer relevant considering the rapid development of science and technology. Today's learning resources are not only teachers, but now there are many learning resources that can be used as learning resources (Sanjaya, 2016). The optimization of the utilization of learning resources can be achieved by optimizing the role of teachers in learning. In current learning paradigm, teaching is more than a process of delivering knowledge from the teachers to students. Teacher is not the only source of learning for students. Teaching is an activity to regulate the learning environment. Learning environment concerns everything which exists around the living environment of students. The learning environment is not only about the class. Structuring the learning situation in the classroom is one of the keys to the success of the learning environment in the classroom. The teacher has the authority to regulate the students' learning environment.

Nowadays, students' learning environment is not only about the real world around it. Students are active adolescents whose surroundings also have another reality which is more inherent than the real world, namely the digital world. The digital world is currently packaged by media and technology where the students are able to get a lot of information. Seeing these signs, the world of education certainly encounters the challenges of this era that should not be ignored. Teachers, as the spearhead of education, will they remain silent with the new transformation in the world of media and technology? Forcing the students not to touch these two things is not an act of responding to the challenges of this era.

\section{Research Method}

This research is a field research which was carried out through inductive thinking processes using qualitative approach. The qualitative approach was chosen by the researchers because it is appropriate to get an in-depth description of the implementation of media literacy and technology utilization in social studies learning by teachers in the city of Semarang. The data in this research were in the form of information or facts obtained through observation or research in the field that can be analyzed in order to understand a phenomenon or to support a theory (Sekaran, 2007). In qualitative research, the data are presented in the form of a description. The data collected in this research were in accordance with the focus of the research. According to Patton, the data retrieval in this research was conducted by using snowball sampling, a method where key informants designate people who know the problems which will be observed to complete their statements and people will be appointed by and appoint others if the information is not sufficient and so on (Patton, 1990). 
The data sources in this research can be divided into two, namely human being and non-human being. Human being data source functions as a subject or key informant and the data obtained through the informants are in the form of soft data. Non-human being data source is in the form of documents which are relevant to the focus of the research, such as events or activities that are related to the focus of the research. The data collection in this research used three techniques offered by Bogdan and Biklen (Biklen, 2008), namely

1) In-depth interviews

2) Participant observation

3) Study document.

Data validity checking (trustworthiness) is a very important and inseparable part of a qualitative research. According to Miles and Huberman, the implementation of data validity checking is based on four criteria, namely credibility, transferability, dependability, and confirmability. The analysis of the data in this research includes

1) Data reduction (data reduction), which is classifying, directing, removing unnecessary and organizing the data;

2) Data presentation (data displays), which is finding meaningful patterns of relationships and providing the possibility of drawing conclusions; and

3) Conclusion drawing/verification (Huberman, 2005).

\section{Results and Discussion}

\subsection{Students in the global vortex}

Teenagers spend an average of more than seven hours per day to access media such as television, computers, the internet, video game, and smartphone. The positive impact of accessing media for teenagers and children is the transfer of information about various knowledge and it can also strengthen friendship (social relation). However, there are also negative impacts caused by the media namely triggering aggressive behavior, sexual harassment behavior, the disruption of healthy lifestyles, and decreasing academic performance of children and teenagers. The impact of the media on children and teenagers is not only reducing their sleep time or study time but also affecting their daily behavior. Children and teenagers tend to observe and imitate what they witness through the media. Media is the teacher for children and teenagers who also have a role in their daily lives (V.C. Strasbuger, 2010).

At the international level, globalization is a blessing but it could also be a disaster because the opportunity for countries to interact to each other is increasingly wide open every second. To influence and to be influenced have become the menu of daily life (Purwasito, 2015). The reality says that today, students are in the global vortex, both consciously and unconsciously. The use of smartphones has become a part of the lives of students where they are part of the "players and viewers" who spend much time on social media (Kanbul, S., Kallagov, T., Rubanik, V., Khairullina, E., \& Ribakova, 
2019). As players, they spread influence according to the scale and range. The other side states that it is possible for students to be the targets who are affected by the global uproar that they do not necessarily understand. This thing has the potential to become a global irony whose impact will exist on future lives.

\subsection{Teachers and their efforts to face the dynamic of media}

Learning media experiences the development from time to time. The development of media is in line with the advances in information and communication technology, as well as individual necessity from the point of view of necessity. Existing necessity leads to various considerations, namely ease and practicality. Learning media which have developed so far have fulfilled the criteria of their users to get convenience and practicality as a means of educators/teachers as the spearhead of education. There was a transformation of learning media from the analogue to digital. Analog media is considered not to fulfil the element of convenience and practicality. Besides, it is no longer relevant to the development of this era which produces sophisticated facilities. These sophisticated means deliver people to the digital era. Software and hardware technology produce new variant equipment which also contribute to the transformation of learning media.

Media allow students to be more involved in learning (Silberman, 2006). The most important thing in learning is to lead the students towards the efforts to gain experience in learning. There are various dimensions of learning experiences that can be experienced by students, namely the conceptual dimensions and practical dimensions. Regarding the teacher's efforts to take the students to both dimensional exploration spaces, the media have a central and strategic position for the students to get a more meaningful learning experience.

Teachers are human resources which must always be dynamic. Age development cannot be responded passively/coldly by the education sector. Education must be able to break down the conditions of the era so that it can still contribute to the goodness of civilization (Lunenburg, 2017). Today, the condition of teachers in Semarang city on average has used technology. They own the technology and have the ability to operate technological devices in their daily lives. The technological devices that are used directly or indirectly experience the allusion with their domains as a teacher or an educator. The consequence of the existence of these domains is the emergence of new questions, namely how much is the benefit of the existence of technological devices for their profession?

Based on the information of informants, the teacher's level of mastery of information, most teachers have applied communication and technology. The majority of students use smartphones in their daily life (Denizalp, H., \& Ozdamli, 2019). These phenomena are sufficient precondition for teachers/educators to transform the digitalization of learning media. Teachers who are still classified as productive age (not close to retirement age) are considered to have the willingness and skills to utilize digitalbased learning media. Students who have sophisticated digital devices may indicate high potential for digital media to be empowered in the learning. Therefore, the mastery 
of the knowledge and skills of using learning media especially digital-based is a primary need in the current global education era.

In the digital era, education allows the opening of new spaces in the learning dimension. These new spaces include learning resources and learning facilities. The education in the global era requires the teachers to be able to show learning resources for students in a variety of ways. This is because the old opinion about the teacher as the only source of learning for students is considered difficult to maintain. Learning media is a means for students to learn more meaningful learning. The meaning of real learning is not to make students smart, but to shape them into someone who has true learning spirit. The teacher's skill in interpreting variants of media literacy in learning is a stimulus for students to find their true learning style.

Learning media have criteria to be effective and efficient as supporting factors to realize the ideal learning. Based on the information from the informants (education practitioners), good learning media must meet two main criteria, namely:

1) Easy to realize

2) Easy to apply.

Firstly, the realization of good learning media does not have to be able to be realized / produced by certain teachers with specific expertise only. All teachers are able to develop media according to their individual needs and creativity. The essence is not how great the learning media created is, but how meaningful it is for the learning. Secondly, the application / implementation of learning media must be in accordance with the intended learning objectives. The implementation of learning activities is a manifestation of a system which has been designed in such way. Learning objectives are tiered components which are in accordance with the curriculum message from national to instructional goals. Learning media is an instructional tool which is ideally able to help teachers and students to achieve learning goals (Beetlestone, 2012).

Students are strategic components in the learning system. Behind their figures as human beings who are undergoing a process of transformation, a student is a child who is in the process to adolescence. The process to adolescence is a crucial point because it will affect the maturation process. The process of rejuvenation and maturation of today's students goes together with the phenomenon of the development of digital media which is increasingly being much more difficult to be overtaken by some people, especially teachers/educators. There is a tendency that students are individuals who are more active and adapt very well to the development of the media. The school policy that prohibits students from carrying smartphones on the one hand is considered conservative because it is not relevant to the current situation. Teachers should not remain silent in seeing the signs occurred in the space and around the world of adolescence. Teachers also need to be personally transformative in facing the challenges of this era. This is not in order to be more proficient/ skilled in using media, but as an effort to save the students from falling into a pool of problems as a negative impact of the presence of contemporary digital media.

Teachers/educators are individuals who are required to fulfil all the complexity of the required competencies (Muijs, 2008). The existence of media in learning is the result / product of the synergy of these competencies. As a professional, a teacher needs 
to fulfil all indicators to make himself/herself a person who can complete his noble tasks as a learning transformer. The parameters in indicators which are not achieved is the cause of the presence of the obstacles in realizing learning media.

Personally, teacher is a unique individual. The uniqueness is manifested in their behaviour in various learning activities. In addition to the phenomenon or the signs of learning experiences, there are also another item in learning phenomena, namely teaching experience. So far, teaching experience of teachers has been measured by the parameters of how long one became a teacher. The parameter uses the temporal approach / time dimension which apparently does not always guarantee someone to be an ideal teacher. Learning is a systematic activity; the use of good learning media cannot only rely on the length of time a person becomes a teacher. That non-technical barriers are considered to be a limiting factor for teachers to be able to produce quality learning media.

\section{Conclusion}

Based on various studies that have been conducted through the procedures of this research, it can be concluded that in-school learning aspect, education cannot avoid the development of global dynamics with high rotational speed. Social Science learning in Junior High School is unlikely to resist the effect of global flows through highly sophisticated digital technology-based media channels. Social Science teachers in Semarang City have exerted their efforts to face the global challenges through digital media technology. Digital media technology has great potential to support the implementation of Social Science learning that can always answer the challenges of this era.

The schools need to adjust to the development of digital media technology whose development is unstoppable. The form of self-adjustment is the arrangement of moderate regulations. The objective of those regulations is to achieve a balance between shaping students who have good characters and supporting the students to be the next generation with the development of civilization. Social Science teachers as the spearhead of quality teaching need to get the encouragement from various parties to consistently improve their competencies, especially in order to support the media literacy mastery which is potential to give great benefits for learning. The support could be derived from various education stakeholders which include the government, training/skill development institutions, private sectors, universities, and other parties. This research involves schools in the urban environment at Semarang, so the data cannot represent the real setting. Hence, this will be more comprehensive if information is obtained from several schools which represent various social strata. For future research, this limitation may be a good start to conduct similar research with more depth results.

\section{Acknowledgement}

This article is based on our research project 'The Utilization of Media and Technology Literation in Social Science Learning in Semarang'. We would like to say our gratitude to Faculty of Social Sciences, Universitas Negeri Semarang for research funding. 
In addition, we also would like to say thank you for all respondents and participants, so this research will be published.

\section{References}

[1] Beetlestone, F. (2012). Creative Learning; Strategi Pembelajaran untuk Melesatkan Kreativitas Siswa. Bandung: Penerbit Nusa Media.

[2] Biklen, R. C. B. and S. K. (2008). Qualitative Research for Education: An Introduction to Theory and Methods. Boston: Allyn and Bacon.

[3] Denizalp, H., \& Ozdamli, F. (2019). Determination of Student Opinions on Usage of Social Media and Mobile Tools in Student-Teacher, Student-Student Communication. International Journal of Emerging Technologies in Learning (IJET), 14(22), 19-28. Retrieved from https://doi.org/10.3991/ijet.v14i22.11745

[4] Dikdasmen, D. (2016). Desain Induk Gerakan Literasi Sekolah. Jakarta: Direktorat Jenderal Pendidikan Dasar dan Menengath Kementerian Pendidikan dan Kebudayaan. https://doi.org/10.24832/jpnk.v17i6.320

[5] Huberman, M. B. M. and M. A. (2005). Qualitative Data Analysis (2nd ed.). California: Sage Publications.

[6] Kanbul, S., Kallagov, T., Rubanik, V., Khairullina, E., \& Ribakova, L. (2019). Determination of Mobile Addiction and Social Media Addiction Level of Parents and Their Attitudes Towards Usage of Technology. International Journal of Emerging Technologies In Learning (IJET), 14(22), 175-191. Retrieved from https://doi.org/10.3991/ijet.v14i22.11770

[7] Lunenburg, C. F. (2017). Critical Thinking and Constructivism Techniques for Improving Student Achievement. Jurnal National Forum of Teacher Education, 21(3), 1-9.

[8] Muijs, D. and D. R. (2008). Effective Teaching. Yogyakarta: Pustaka Pelajar.

[9] Patton, M. (1990). Qualitative Evaluation and Research Methods (2nd ed.). Newbury Park: Sage Publications.

[10] Purwasito, A. (2015). Komunikasi Multikultural. Yogyakarta: Pustaka Pelajar.

[11] Sanjaya, W. (2016). Strategi Pembelajaran. Jakarta: Kencana Prenada Media Group.

[12] Sekaran, U. (2007). Research Methods for Business. New York: John Wiley \& Sons, Inc.

[13] Silberman, M. L. (2006). 101 Cara Belajar Peserta didik Aktif. Bandung: Nusamedia dan Nuansa.

[14] V.C. Strasbuger, A. B. J. and E. D. (2010). Health Effects on Media on Children and Adolescents. Pediatrics; Official Journal of the American Academy Pediatrics

\section{$7 \quad$ Authors}

Khoirul Anwar is a member of lecturer in Department of Social Science Education, Faculty of Social Sciences, Universitas Negeri Semarang, Central Java, Indonesia. His main research interest are Social Sciences Education, History Education, and Educational Communication.

Fitri Amalia Shintasiwi is a lecturer in Department of Social Science Education, Faculty of Social Sciences, Universitas Negeri Semarang. Her main research interests are intercultural communication and interaction, multiculturalism using discourse analysis approach. 
Ferani Mulianingsih is a member of lecturer in Department of Social Science Education, Faculty of Social Sciences, Universitas Negeri Semarang. Her main research interest are Social Sciences Education and Geography Education.

Article submitted 2020-01-13. Resubmitted 2020-02-19. Final acceptance 2020-02-22. Final version published as submitted by the authors 